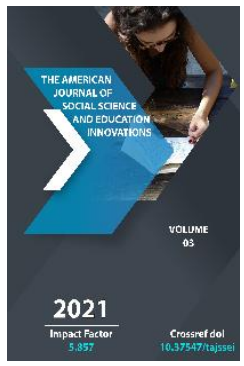

\title{
A New Approach To The Organization Of Practical Training In Professional Educational Institutions
}

\author{
Shoykulov Bakhtiyor Bakirovich \\ Institute Of Pedagogical Innovations, Vocational Education Management And Retraining And \\ Advanced Training Of Teachers, Tashkent, Uzbekistan
}

Journal Website:

http://usajournalshub.c

om/index,php/tajssei

Copyright: Original content from this work may be used under the terms of the creative commons attributes 4.0 licence.

\section{ABSTRACT}

The article discusses the goals and objectives of the organization experimental sites in the effective and targeted organization of practical training and internships, the implementation of tasks set in the curriculum, the formation of professional and entrepreneurial competencies and the creation of conditions for the conduct of research work of masters of industrial education, the popularization of exemplary work.

\section{KEYWORDS}

Experimental work, innovative landfills, training laboratory and workshop equipment, landfill and experimental land.

\section{INTRODUCTION}

Today, modern innovative technologies are rapidly entering all sectors of the economy in Uzbekistan. Intensive technologies are being introduced in industry, agriculture, transport and services, providing high value, high productivity, productivity and economy, and a wide range of modern innovations in manufacturing. Thousands of new 
technological jobs are being created with the involvement of millions of US dollars of foreign investment in these processes.

Accordingly, the new vocational education system will train mid-level personnel who can make a worthy contribution to economic development in the regions and industries, train young people to ensure their well-being through skilled labor, innovative and creative approach to their work, creativity, intellectual, cultural and spiritual potential. the task of creating a methodology for the formation of such competencies.

Another important aspect is that from now on, based on the opportunities of vocational education institutions and vocational training centers, entrepreneurship in the field of greenhouses, animal husbandry, beekeeping, fisheries, rabbit breeding, poultry, horticulture, lemon growing, vegetable growing, production and services. and the establishment of small business networks.

In order to carry out this work, it will be necessary to establish experimental plots in each vocational education institution.

\section{MATERIALS AND METHODS}

The material and technical base of the educational institution, including training laboratories and workshops, experimental landfills, landfills, based on the specifics of the profession and specialization, will be created "Innovation landfills", where students will have practical training and education. operations are performed.

At the Institute of Pedagogical Innovations, Vocational Education Management and Retraining and Advanced Training of Teachers, senior staff of the Institute for Practical Training of Students of Vocational Education Institutions, including the organization of experimental work in the educational institution on quality and effective organization of training and internships. The module "Introduction" is introduced.

The purpose of experimental work in a professional educational institution is to fulfill the tasks set in the curriculum, to form the professional competencies of students, to create conditions for research work of teachers and masters of industrial education, production and testing of new products, modern technological processes. use is.

Also, the effective use of existing training laboratories, workshops, landfills and experimental lands through the organization of experimental work in a vocational school, the acquisition of knowledge, skills and competencies to guide children from lowincome families to entrepreneurship and business, ultimately income developing students 'professional knowledge and skills in shaping, analyzing experimental work, and popularizing exemplary work.

For the first time in Uzbekistan, starting from the current academic year, entrepreneurshiporiented curricula have been piloted in vocational education institutions.

\section{RESULT AND DISCUSSION}

The organization of experimental work in the educational institution is the targeted use of existing training laboratory and workshop equipment, experimental land, training of poor, unemployed citizens in modern professional and entrepreneurial skills, training of qualified personnel, employers and 
organizations and higher education. ideas and proposals for the establishment of cooperation with educational institutions, finding extra-budgetary funds in educational institutions, the development of entrepreneurial activity and financial and moral stimulation of students, innovative results in the field of professional training of teachers and masters of industrial education, teaching materials and provide support for the dissemination of their developments and the conduct of scientific research.

Vocational educational institutions in their territories or in the relevant employer enterprises and organizations, higher education institutions in the field of production, services and other industries (fisheries, livestock, rabbits, poultry, beekeeping, greenhouses, intensive orchards, cotton, grain, fruit and viticulture, vegetables horticulture, biolaboratory, forestry, silkworm breeding, medicinal plants, banking, courtrooms, catering, hotel management, tourism, etc.).

In order to develop the professional competencies of students and their entrepreneurial knowledge and skills in today's professions and specialties, a number of professional educational institutions are working in the field of production and services (fishing, beekeeping, poultry, rabbit, as well as various greenhouses).

It is planned to conduct practical training of students studying in professions and specialties in vocational education institutions on experimental plots organized on the basis of enterprises and organizations or higher education institutions outside their territories.

\section{CONCLUSION}

In summary, the role of experimental land plots in the organization of practical training in vocational education institutions is important, as they have an impact on the following indicators.

- Creates the basis for the full implementation of the tasks set in the curriculum;

- Promotes the participation of students in various competitions, as well as the formation of their competencies in accordance with the standards of Worldskills;

- There is an opportunity to earn extrabudgetary money in the educational institution;

- Specialists with professional competence are trained in the labor market.

\section{REFERENCES}

1. Resolution of the President of the Republic of Uzbekistan dated August 11, 2020 No PP4804 "On additional measures aimed at attracting poor and unemployed citizens to entrepreneurship, increasing their labor activity and vocational training and employment"

2. Resolution of the Cabinet of Ministers of the Republic of Uzbekistan 2020 Resolution No. 466 of 7 August "On approval of normative legal acts regulating the system of continuing primary, secondary and secondary special vocational education in the Republic of Uzbekistan".

3. Resolution of the Cabinet of Ministers of the Republic of Uzbekistan dated 
September 23, 1998 No 406 "On the program of development and financing of the material and technical base of academic lyceums and professional colleges for 1999-2005".

4. Uraqulov X.A. Methodology of scientific creativity. T .: Fan, 2007.

5. National encyclopedia of Uzbekistan. $4.8 \mathrm{j}$. $\mathrm{T}$.: OME State Scientific Publishing House, 2002.

\section{Websites}

1. www.BoilingFrogProductions.com

2. https://www.youtube.com/watch?v=Ensb WEhTH5W

3. http://profermu.com/ogorod/pomidory/p arnik-p.html

4. https://www.youtube.com/watch?v=N9J5 QSkSoKc

5. https://www.youtube.com/watch?v=d_hqdnbkx8

6. http://tadbirkor-fermer.uz/kuyonchlarnikupajtirish/

7. https://www.youtube.com/watch?v=X_B6 Ze66pgA

8. https://agro-olam.uz/baliqchilik-haqidavideo/

9. https://utube.uz/ru/video/43aca2b638ec3 64 